\title{
The Effects of Pyrethroid and Triazine Pesticides on Fish Physiology
}

\author{
Josef Velisek, Alzbeta Stara and Zdenka Svobodova \\ University of South Bohemia in Ceske Budejovice, Faculty of Fisheries and Protection of \\ Waters, South Bohemian Research Center of Aquaculture and Biodiversity of \\ Hydrocenoses, Research Institute of Fish Culture and Hydrobiology, Vodnany \\ Czech Republic
}

\section{Introduction}

Worldwide pesticide usage has increased dramatically during the past two decades, coinciding with changes in farming practices and increasingly intensive agriculture. Environmental pollution caused by pesticides, especially in aquatic ecosystems, has become a serious problem. Contamination of water by pesticides, either directly or indirectly, can lead to fish kills, reduced fish productivity, or elevated concentrations of undesirable chemicals in edible fish tissue which can affect the health of humans consuming these fish. Residual amounts of pesticides and their metabolites have been found in drinking water and foods, increasing concern for the possible threats to human health posed by exposure to these chemicals. Contamination of surface waters has been well documented worldwide and constitutes a major issue at local, regional, national, and global levels (Cerejeira et al., 2003; Spalding et al., 2003).

Synthetic analogues of the pyrethrins, extracts from the ornamental Chrysanthemum cinerariaefolium, have been developed to circumvent the rapid photodegradation problem encountered with the natural insecticidal pyrethrins. The widespread use of these insecticides leads to the exposure of manufacturing workers, field applicators, the ecosystem, and the public to their possible toxic effects (Solomon et al., 2001). During investigations to modify the chemical structure of natural pyrethrins, a number of synthetic pyrethroids were produced with improved physical (involatility, lipophilicity) properties and greater insecticidal activity (knockdown). Several of the earlier synthetic pyrethroids have been successfully adapted for commercial use, mainly for the control of household insects. Other more recently developed pyrethroids have been introduced as agricultural insecticides because of their effectiveness against a wide range of insect pests and their nonpersistence in the environment. Synthetic pyrethroids are fairly rapidly degraded in soil and in plants. Ester hydrolysis and oxidation at various sites on the molecule are the major degradation processes. Pyrethroids are strongly adsorbed on soil and sediments, and minimally eluted with water. There is little tendency for bioaccumulation in organisms (Haya, 1989). More than 1,000 pyrethroids have been synthesized since 1973. Their toxicity for non-target organisms is in the parts per billion (Bradbury \& Coast, 1989).

Synthetic pyrethroids are non-systemic insecticides. Type I pyrethroids (e.g. bifenthrin, permethrin) block sodium channels in nerve filaments and cause the 'T-syndrome' in 
mammals. Type II pyrethroids (e.g. cypermethrin, deltamethrin) act by blocking sodium channels and affecting the function of GABA-receptors in nerve filaments. In mammals, type II pyrethroids trigger clinical symptoms known as the 'CS-syndrome' (Roberts \& Hudson, 1999).

Deltamethrin [(S)-a-cyano-3-phenoxybenzyl(1R,3R)-3-(2,2-dibromvinyl)-2,2-dimethylcyclo propan-carboxylate], a widely used pesticide, is among the most effective pyrethroid preparations (Bradbury \& Coast, 1989). Deltamethrin was synthesised in 1974 and first marketed in 1977. It works by paralysing the insect nervous system, giving a quick knockdown effect following surface contact or ingestion. It is commonly used to control caterpillars on apples, pears, and hops, and for the control of aphids, mealy bugs, scale insects, and whiteflies on greenhouse cucumbers, tomatoes, potted plants, and ornamentals. Deltamethrin is the active ingredient in Butoflin, Butoss, Butox, Cislin, Crackdown, Cresus, Decis, Decis-Prime, K-Othrin, and K-Otek. It is the first potent and photostable insecticide belonging to the type II pyrethroid group. In the summers of 1991 and 1995, the pesticide caused massive eel (Anguilla anguilla) kills in Lake Balaton, Hungary following application for mosquito control. In 1995, the presence of deltamethrin was demonstrated in several other fish species and in sediment samples taken from the lake (Balint et al., 1995). The mechanism of its toxicity in fish is the same as that of other pyrethroids containing -cyano-3phenoxybenzyl groups. They block the sodium channels of nerve filaments, lengthening the depolarisation phase. They also affect the GABA receptors in the nerve filaments (Eshleman \& Murray, 1991).

Cypermethrin [(RS)-a-cyano-3-phenoxybenzyl(1RS)-cis,trans-3-(2,2-dichlorovinyl)-2,2dimethylcyclopropane-carboxylate], another widely used pyrethroid pesticide, is among the most effective pyrethroid preparations (Bradbury \& Coats, 1989). Cypermethrin is the active ingredient in Ammo, Arrivo, Barricade, Basathrin, Cymbush, Cymperator, Cynoff, Cypercopal, Cyperguard, Cyperhard, Cyperkill, Cypermar, Demon, Flectron, Fligene, Kafil, Polytrin, Siperin, and Super. The mechanism of its toxicity in fish is the same as that of other type II pyrethroids (Hayes, 1994). Cypermethrin is a synthetic pyrethroid used for the control of ectoparasites infesting cattle, sheep, poultry, and some companion animals. Recently, the compound has been used for the control of ectoparasite infestations (Lepeophtheirus salmonis and Caligus elongatus) in marine cage culture of Atlantic salmon, Salmo salar (Treasurer \& Wadsworth, 2004).

Bifenthrin [2-methylbiphenyl-3-ylmethyl (Z)-(1RS, 3RS)-3-(2-chloro-3,3,3-trifluoroprop-1enyl)-2,2-dimethylcyclopropane-carboxylate], a newer member of the synthetic pyrethroid family, is a contact insecticide and acaricide used on a variety of crops, on stored grain, and as a preconstruction termite barrier. Bifenthrin is the active ingredient in Talstar, Bifenthrine, Brigade, Capture, Torant, and Zipak. It is a type I pyrethroid (Shan et al., 1997), and has some structural similarities to cypermethrin, tetramethrin, and permethrin but is characterised by greater photostability and insecticidal activity than earlier pyrethroids (Yadav et al., 2003). It is effective as a gut or contact insecticide that affects the nervous system of vertebrates and invertebrates. Bifenthrin acts on sodium channels at the nerve cell endings to depolarize the presynaptic terminals. It also affects cellular ATPase production (Roberts and Hutson, 1999).

Triazines (a six-membered ring containing three carbon and three nitrogen atoms) are some of the oldest herbicides, with research initiated on weed control properties during the early 1950s. Triazine herbicides are categorized into two groups, the asymmetrical triazines, such as metribuzin, and the symmetrical triazines. The major commercially used symmetrical 
triazines are simazine, atrazine, propazine, cyanazine, ametryn, prometryn, prometon, and terbutryn. As a chemical family, the triazines are a group of pesticides with a wide range of uses. Most are used in selective weed control programs, others, such as prometon, have no selective properties, which makes them suitable for use on industrial sites (Fan et al., 2007). A unique member of this family is cyromazine, which is an insect growth regulator useful in livestock, vegetable, and ornamental plant applications through interference with insect moulting and pupation. As herbicides, the triazines may be used alone or in combination with other herbicide active ingredients to increase the weed control spectrum (Solomon et al., 1996). Triazine's herbicidal activity is mediated through the inhibition of photosynthesis (Das et al., 2000) by blocking electron transport during the Hill reaction of photosystem-II (DeLorenzo et al., 2001). It binds to a plastoquinine-binding niche on D1, a 32-kD protein encoded by the psbA gene of the photosystem-II reaction complex (Das et al., 2000). In plants it is metabolised by oxidation to 2-hydroxy derivates and by side-chain de-alkylation (Roberts et al., 1998).

Terbutryn [(N2-tert-butyl-N4-ethyl-6-methylthio-1,3,5-triazine-2,4-diamine] is used as a selective pre- and early post- emergence control agent of most grasses and many annual broadleaf weeds on a variety of crops, such as cereals, legumes, and tree fruits. It is also used as an herbicide for control of submerged and free-floating weeds and algae in water courses, reservoirs, and fish ponds (Tomlin, 2003). Terbutryn is the active ingredient in Prebane, Igran, Shortstop, Clarosan, GS 14260, Plantonit, Gesaprim Combi (with Atrazine 1:1), Senate (with trietazine), and Igrater 50WP (with metobromuron 1:1). Terbutryn is moderately toxic to fish (Meister, 1992). Kidd \& James (1991) reported the mean lethal toxicity of terbutryn (96 h LC50) $4 \mathrm{mg} / \mathrm{L}$ for common carp and $3 \mathrm{mg} / \mathrm{L}$ for rainbow trout. Large quantities of terbutryn have been used since the mid-1980s (Larsen et al., 2000). Terbutryn degrades slowly, with a half-life of 240 and 180 days in pond and river sediments, respectively (Muir et al., 1980). Its tendency to move from treated soils into water compartments through runoff and leaching has been demonstrated, and residual amounts of terbutryn and its metabolites have been found in drinking water and industrial food products long after application (Konstantinov et al., 2006). The application of terbutryn has been banned in many countries because it has the potential to bioaccumulate in organisms, but is still present in waters (Rioboo et al., 2007). Preparations containing terbutryn have not been registered in the Czech Republic since 2005, but its presence can be still detected in the environment. The highest concentration reported in surface water in the Czech Republic is $0.02 \mu \mathrm{g} / \mathrm{L}$ (Velisek et al., 2010). In Europe terbutryn levels can reach values up to $5.6 \mu \mathrm{g} / \mathrm{L}$ (Quednow \& Puttmann, 2007).

Simazine (6-chloro- $N, N$ '-diethyl-1,3,5-triazine-2,4-diamine) was introduced by the Swiss company J. R. Geigy (Cremlyn, 1990) in 1956 and is also a member of the triazine family of compounds. It is a selective herbicide used for control of annual broadleaf and grass weeds in raspberries, loganberries, highbush blueberries, apples, asparagus, and ornamentals. Non-crop uses include total weed control in industrial areas, at airports, along shelterbelts and rights-of-way, and for aquatic weed control in ditches, farm ponds, fish hatcheries, aquaria, and fountains (Arufe et al., 2004). Simazine is the active ingredient in Princep Caliber 90, Princep Liquid, Caliber, Cekusan, Cekusima, Framed, Gesatop, Simadex, Simanex, Simtrol, Tanzine, Totazine, and other trade name herbicides as well as in the algicide Aquazine. Simazine is slightly toxic to fish. Hashimoto \& Nishiuchi (1981) give a value of $40 \mathrm{mg} / \mathrm{L}$ for $48 \mathrm{hLC} 50$ for common carp (Cyprinus carpio L.) and goldfish (Carassius auratus). Simazine degrades slowly, with an aerobic soil half-life of 91 days and an anaerobic aquatic half-life of 664 days. It is expected to be persistent in the environment, resulting in 
the potential for this chemical to reach the aquatic environment through run-off. Simazine may also be expected to leach into groundwater systems due to high mobility in soil. It has been found to photo-degrade in soil, but to be resistant to aqueous abiotic reactions. Based on a low vapour pressure, volatilization is not expected to be an important process for simazine (Wackett et al., 2002). Simazine does not biomagnify in the food web, and its bioaccumulation potential is low, with bioconcentration factors $(\mathrm{BCF})<100$. The depuration half-life in fish is $<7$ days if the organism is transferred to uncontaminated water following exposure, indicating that simazine is rapidly excreted or metabolized (Niimi, 1987). Simazine is the second most commonly detected pesticide in surface and ground waters in the U.S., Europe, and Australia, presumably due to relatively high persistence (Inoue et al., 2006). Its degradation products are detected less frequently than atrazine and other triazine pesticides in the aquatic environment. The highest concentration reported in surface water in the Czech Republic is $0.06 \mu \mathrm{g} / \mathrm{L}$ (Velisek et al., 2009a). In Europe simazine levels reach values up to $5 \mu \mathrm{g} / \mathrm{L}$ (Belmonte et al., 2005). Simazine was the most frequently detected pesticide in 20 counties in California, USA with concentrations ranging from 0.02 to 49.2 $\mu \mathrm{g} / \mathrm{L}$ (US Environmental Protection Agency [US EPA], 1994).

The following is an overview of the ecotoxicological risks presented by pesticides to ecosystems, based on data of the toxicity and effects of pesticide preparations to non-target organisms, especially fish. The objective is to describe whether and how pyrethroids and triazines might affect fish physiology. These two groups of pesticides were chosen because 1) the major negative impact of pyrethroids is their high toxicity to fish (e.g. fish mortality in Balaton in 1991 and 1995) combined with their use for control of some parasitic diseases in fish, e.g. Lepeophtherius salmonis in salmon farming; and 2) Triazine residues accumulate in fish tissue and s-triazines have been identified as relevant in a study on the prioritizing of substances dangerous to the aquatic environment in the member states of the European Community and are included in the EU Priority Pollutants List and the US EPA priority pollutants list.

\section{Experimentation}

\subsection{Pyrethroids}

The toxic effect was assessed by the results of acute toxicity tests and results of haematological, biochemical, and histological examination of rainbow trout and common carp after exposure to selected pyrethroid pesticides. We selected three active pyrethroidbased substances: deltamethrin (ingredient of Decis EW 50 - 50 g/L deltamethrin), cypermethrin (ingredient of Alimetrin $10 \mathrm{EM}-100 \mathrm{~g} / \mathrm{L}$ cypermethrin), and bifenthrin (ingredient of Talstar EC 10 - $100 \mathrm{~g} / \mathrm{L}$ bifrenthrin).

\subsubsection{Acute toxicity test}

The acute toxicity test on rainbow trout and common carp with selected pyrethroid pesticides followed the OECD Directive No. 203 'Fish, acute toxicity test.' Seven concentrations and a control were used in the basic test. Ten fish were used for each concentration and for the control group. The test was conducted semi-statically for $96 \mathrm{~h}$. Fish mortalities were recorded at 24, 48, 72, and 96 h. Fish status and behaviour, along with water temperature, $\mathrm{pH}$, and oxygen saturation were monitored throughout the test. The bath was changed every $12 \mathrm{~h}$. The LC50, LC0, and LC100 values for the respective time intervals were determined by probit analysis (EKO-TOX 5.1 software). 


\subsubsection{Biochemical, haematological profile, and histopathological examination following pyrethroid exposure}

Examinations were performed the $96 \mathrm{~h}$ exposure period with deltamethrin, cypermethrin, and bifenthrin at an exposure level of 96hLC50. Rainbow trout or carp, respectively in the control group were monitored concurrently. The test was performed in sixteen 3001 tanks. Each tank contained 20 rainbow trout or common carp, i.e. six tanks with 96hLC50 of deltamethrin, cypermethrin, or bifenthrin, and one control tank with rainbow trout and one control tank with carp. Tanks for all treated fish and controls were replicated, Presence of the tested substance (above $80 \%$ of the nominal concentration) was ensured through a $12 \mathrm{~h}$ exchange of the water bath. Determination of pyrethroid concentration in water was measured using gas chromatography (Mekebri et al., 2008).

Forty-eight experimental (8 fish from each pesticide duplicated) carp or rainbow trout and sixteen control carp or rainbow trout were selected at random and used for haematological, biochemical, and histological examination at the end of the $96 \mathrm{~h}$ exposure. Blood was sampled from the vena caudalis, using an $18 \mathrm{G} \times 11 / 2$ in syringe. Fish were not anaesthetized prior to blood sampling, as they were calm due to low water temperature and there was no danger of tissue trauma or handling stress. Heparin was used as an anticoagulant (Heparin inj., Leciva, Czech Republic) at a concentration of 40 I.U. heparin sodium salt in $1 \mathrm{ml}$ blood. The indices used to evaluate the haematological profile included erythrocyte count (RBC), haemoglobin concentration $(\mathrm{Hb})$, haematocrit $(\mathrm{PCV})$, mean erythrocyte volume $(\mathrm{MCV})$, mean colour concentration $(\mathrm{MCHC})$, erythrocyte haemoglobin $(\mathrm{MCH})$, leukocyte count (Leuko), and the differential leukocyte count (Leukogram). The procedures were based on unified methods for haematological examination of fish (Svobodova et al., 1991).

Blood was sampled by $v$. caudalis as mentioned above. Plasma was obtained by centrifuging blood samples in a cooled centrifuge $\left(4{ }^{\circ} \mathrm{C}, 837 \times \mathrm{g}\right)$. Plasma samples were held at $-80{ }^{\circ} \mathrm{C}$ until analysis. Biochemical indices included glucose (GLU), total proteins (TP), albumins (ALB), total globulins (GLOB), ammonia $\left(\mathrm{NH}_{3}\right)$, tricylglycerols (TAG), aspartate aminotransferase (AST), alanine aminotransferase (ALT), lactate dehydrogenase (LDH), gama-glutamyltransferase (GGT), creatine kinase (CK), lactate (LACT), alkaline phosphatase (ALP), calcium $\left(\mathrm{Ca}^{2+}\right)$, magnesium $(\mathrm{Mg})$, and inorganic phosphate (PHOS). For the biochemical analysis of blood plasma, the VETTEST 8008 analyzer (IDEXX Laboratories Inc., Maine, USA) was used.

For histological studies, gill, skin, liver, cranial and caudal kidney, and spleen were fixed in a solution containing ethanol, formalin, and acetic acid (ALFAC) and stored in 70\% ethanol. Tissues were embedded in paraffin, sectioned $(5 \mu \mathrm{m})$, and the slides stained with haematoxylin and eosin (H\&E). The sections were examined by light microscopy, using as reference Takashima \& Hibiya (1995), and photographed using a digital camera.

\subsection{Triazines}

The effect of triazines was assessed by the results of biometric, haematological, biochemical, liver biomarker, and histological examination of common carp following long-term (chronic) exposure to selected triazine pesticides. From triazine we selected two active substances: terbutryn (Sigma Aldrich, Czech Republic, chemical purity 99.2\%) and simazine (Sigma Aldrich, Czech Republic, chemical purity 99.5\%).

Fish were acclimatized for 10 days before the beginning of the experiment and fed commercial food. The experiment was a semi-static assay conducted over 90 days. One hundred sixty one-year-old common carp were allocated, in groups of 10, to one of three experimental regimes or to an untreated control group for each active substance. The 
conditions were duplicated for a total of sixteen groups, each held in an aquarium containing $200 \mathrm{~L}$ water. Aquaria for all treated fish and controls were replicated, and fish were transferred daily to the replicate aquarium containing freshly diluted terbutryn or simazine at the appropriate concentration, or freshwater for the controls. Fish were fed commercial fish pellets at about $1 \%$ body weight per day in two feedings. Terbutryn and simazine concentrations were checked daily by high performance liquid chromatography HPLC (Katsumata et al., 2005; Richter \& Nagel, 2007).

The experimental fish were exposed to terbutryn at the following concentrations in water: Group 1, $0.02 \mu \mathrm{g} / \mathrm{L}$ (reported environmental concentration in Czech rivers); Group 2, 0.2 $\mu \mathrm{g} / \mathrm{L}$; and Group 3, $2 \mu \mathrm{g} / \mathrm{L}$. The terbutryn concentrations of $0.2 \mu \mathrm{g} / \mathrm{L}$ and $2 \mu \mathrm{g} / \mathrm{L}$ corresponded to the $0.0005 \% 96 \mathrm{hLC} 50$ and $0.005 \% 96 \mathrm{hLC} 50$ determined for carp. The experimental fish were exposed to simazine at the following concentrations in water: Group 1, $0.06 \mu \mathrm{g} / \mathrm{L}$ (reported environmental concentration in Czech rivers); Group 2, $2 \mu \mathrm{g} / \mathrm{L}$; and Group 3, $4 \mu \mathrm{g} / \mathrm{L}$. The simazine concentrations of $2 \mu \mathrm{g} / \mathrm{L}$ and $4 \mu \mathrm{g} / \mathrm{L}$ corresponded to the $0.5 \% 48 \mathrm{hLC} 50$ and $1 \% 48 \mathrm{hLC} 50$ for carp.

\subsubsection{Biochemical, haematological profile, liver biomarkers, and histopathological examination after triazine exposure}

After 90 days exposure, the fish were individually sampled and weighed. Eight fish from each replicate of each group were examined to determine biometric parameters, and haematological, biochemical, and histopathological profiles.

Blood was drawn from the $v$. caudalis and samples stabilized with 50 IU sodium heparin 1 $\mathrm{mL}$ blood. Erythrocyte count, haemoglobin concentration, haematocrit, mean erythrocyte volume, mean colour concentration, erythrocyte haemoglobin, leukocyte count, and the differential leukocyte count, were determined (Svobodova et al., 1991).

Blood was separated by centrifugation at $12000 \mathrm{xg}$ for $10 \mathrm{~min}$ at $4{ }^{\circ} \mathrm{C}$. Plasma samples were held at $-80^{\circ} \mathrm{C}$ until analysis. Biochemical indices evaluated included glucose, total protein, albumin, total globulins, ammonia, triacylglycerols, aspartate aminotransferase, alanine aminotransferase, gama-glutamyl-transferase, lactate dehydrogenase, creatine kinase, creatine (CREA), lactate, amylase (AMYL), lipase (LIPA), alkaline phosphatase, calcium, magnesium, and inorganic phosphate. For the biochemical analysis of plasma, the VETTEST 8008 analyzer. Vitellogenin (VTG) and 11-ketotestosterone (KT) in plasma was measured using pre-coated ELISA kits (Biosense Laboratories Norway) according to the manufacturer's instructions. The use of carp VTG ELISA for determination of vitellogenin in carp was validated by Flammarion et al. (2000). Absorbance was measured using an SLT Spectra (A5082) set at $492 \mathrm{~nm}$ for VTG and at $420 \mathrm{~nm}$ for KT detection.

After blood sampling, body weight (BW) and standard length (SL) were recorded. Condition factor $(\mathrm{CF})$ of each fish was calculated according to the formula $\mathrm{CF}=\mathrm{BW}(\mathrm{g}) / \mathrm{SL}$ $(\mathrm{cm})^{3} \times 100$. Liver weight $(\mathrm{LW})$ and spleen weight $(\mathrm{SW})$ were determined, and a hepatosomatic index (HSI) for each fish was calculated (HSI = LW/BW x 100).

Samples of liver were taken for biomarker examinations. The tissue was quickly removed, immediately frozen, and stored at $-80^{\circ} \mathrm{C}$ until analysis. Liver samples were homogenized in buffer $(0.25 \mathrm{M}$ saccharose, $0.01 \mathrm{M}$ TRIS and $0.1 \mathrm{mM}$ EDTA) and centrifuged at $10000 \mathrm{x}$ for $15 \mathrm{~min}$ at $4{ }^{\circ} \mathrm{C}$. The supernatant was transferred to ultracentrifugation tubes and centrifuged again at $100000 \times g$ for $1 \mathrm{~h}$ at $4{ }^{\circ} \mathrm{C}$. The supernatant was drained, and pellets were washed with buffer and resuspended in buffer. This suspension was put into individual Eppendorf tubes. Before the enzymes were assayed, microsomal protein concentrations were 
determined by the Lowry method (Lowry et al., 1951). The hepatic ethoxyresorufin-Odeethylase (EROD) activity was determined spectrofluorometrically. In the presence of NADPH, EROD activity converts the substrate ethoxyresorufin, which is a fluorescent product. Standard phosphate buffer, NADPH, and suspension adequate for $0.2 \mathrm{mg} / \mathrm{mL}$ protein were put into a cell. Ethoxyresorufin was added, and the increase in fluorescence was monitored for $5 \mathrm{~min}$ (excitation/emission wavelengths were 535/585 nm). The EROD activity was subsequently calculated based on comparison with fluorescence of the standard (resorufin) of known concentration. Total cytochrome P450 (Cyt P450) was determined by visible light spectrophotometry at $400-490 \mathrm{~nm}$ on the basis of the difference between absorbance readings at 450 and $490 \mathrm{~nm}$, and the values were transformed to final concentrations. Measurements were made after cytochrome reduction by sodium dithionite and after the complex with carbon oxide was formed (Siroka et al., 2005).

Thawed liver samples were extracted with phosphate buffer ( $\mathrm{pH} 7.2)$ and homogenized. The homogenates were centrifuged $\left(10000 \times \mathrm{g}\right.$ for $10 \mathrm{~min}$, at $\left.4{ }^{\circ} \mathrm{C}\right)$ and supernatants used for determination of GST, GSH, and protein concentration. Glutathione-S-transferase activity was measured spectrophotometrically using $25 \mathrm{mM}$ 1-chloro-2,4-dinitrobenzene (CDNB) as a substrate and $10 \mathrm{mM} \mathrm{GSH}$ in phosphate buffer saline (pH 7.2) (Habig et al., 1974). Reduced glutathione was determined according to the method of Ellman (1959) using $1 \mathrm{mM} 5,50$ dithiobis-2-nitrobenzoic acid (DTNB) as a substrate. Absorbance of GSH-DTNB conjugate was assessed at $412 \mathrm{~nm}$, and GSH concentrations were calculated according to the standard calibration. Protein concentration was quantified with the Bicinchoninic Acid Protein Assay Kit (Sigma-Aldrich) using bovine serum albumin as standard.

For histological studies, the liver, spleen, cranial and caudal kidney were fixed in a solution containing ethanol, formalin, and acetic acid, and stored in $70 \%$ ethanol. Tissues were embedded in paraffin, sectioned $(5 \mu \mathrm{m})$, and the slides stained with H\&E. The sections were examined by light microscopy, and photographed using a digital camera.

\subsection{Statistical analysis}

Statistical analysis was carried out using Statistica software 8.0 for Windows (StatSoft). Data were first tested for normality (Kolmogorov-Smirnov test) and homoskedasticity of variance (Bartlett's test). If those conditions were satisfied, one-way analysis of variance (ANOVA) was employed to determine whether there were any significant differences in measured variables between control and experimental groups. When a difference was detected $(P<$ 0.05), Tukey's multiple comparison test was applied to identify which treatments were significantly different. If the conditions for ANOVA were not satisfied, the non-parametric Kruskal-Wallis test was used.

\section{Results}

\subsection{Pyrethroids}

For the acute test with deltamethrin, cypermethrin, and bifenthrin, juvenile rainbow trout (Kamloops), 4.10-26.50 g body weight and 65.10-154.00 mm body length and juvenile common carp (mirror carp M 72), 9.90-15.30 g body weight and 59.00-75.20 mm body length, were used. For examinations of pyrethroid effects on haematological, biochemical, and histological profiles, one-to-two-year old rainbow trout of 115.49-309.18 g weight and 241-307 mm body length, and one-to-two-year old common carp of 115.49-832.80 g body weight and 184-366 $\mathrm{mm}$ average body length were used. 


\subsubsection{Acute toxicity of pyrethroids}

The LC0, LC50, and LC100 values of deltamethrin, cypermethrin, and bifenthrin for rainbow trout and common carp juveniles are given in Table 1.

\begin{tabular}{|l|c|c|c|c|c|c||}
\hline \multirow{2}{*}{} & \multicolumn{3}{|c|}{ rainbow trout } & \multicolumn{3}{c||}{ common carp } \\
\cline { 2 - 7 } & LC0 & LC50 & LC100 & LC0 & LC50 & LC100 \\
\hline deltamethrin & 0.50 & 1.00 & 2.50 & 2.14 & 3.25 & 6.08 \\
\hline cypermethrin & 1.98 & 3.14 & 4.96 & 1.82 & 2.91 & 4.64 \\
\hline bifenthrin & 1.04 & 1.47 & 2.09 & 2.15 & 5.75 & 10.51 \\
\hline
\end{tabular}

Table 1. Acute toxicity of pyrethroids in rainbow trout and common carp juveniles (value $\mu \mathrm{g} / \mathrm{L}$ ) (Dobsikova et al., 2006; Velisek et al., 2006a,b, 2007, 2009b,c).

In the course of acute exposure to pyrethroid pesticides, the following clinical symptoms were observed: increased respiration, loss of coordination, and fish lying on their flank and moving in this orientation. Subsequent short excitation stages with convulsions, jumping above the water surface, and moving in circles alternated with resting. Necropsy performed after the acute toxicity test revealed increased watery mucus on body surfaces. The body cavity contained excess fluid and showed congestion of visceral vessels.

\subsubsection{Biochemical examination after pyrethroid exposure}

Acute exposure to deltamethrin in rainbow trout was associated with a significantly $(P<$ $0.05)$ lower concentration of GLU, ALT, and significantly $(P<0.05)$ greater of TP, ALB, $\mathrm{NH}_{3}$, AST, and $\mathrm{Ca}^{2+}$ compared to controls. The common carp exposed to deltamthrin exhibited significantly higher $(P<0.05)$ value of $\mathrm{NH}_{3}, \mathrm{AST}$, and ALT compared to controls.

Acute exposure to cypermethrin resulted in a significantly $(P<0.01)$ lower concentration of ALP and significantly $(P<0.01)$ higher concentration of $\mathrm{NH}_{3}, \mathrm{AST}, \mathrm{LDH}, \mathrm{CK}$, and LACT in rainbow trout compared to controls fish. In common carp cypermethrin resulted in a significant $(P<0.01)$ lower in TP, ALB, GLOB, $\mathrm{NH}_{3}, \mathrm{LDH}$, and ALP, and a significant $(P<$ 0.01 ) higher in GLU, LACT, and CK levels compared to controls.

Acute exposure to bifenthrin resulted in significantly $(P<0.01)$ lower $\mathrm{NH}_{3}$ and significantly $(P<0.01)$ higher concentrations of GLU, LDH, ALP, and CK in rainbow trout compared to control trout. Common carp exposed to bifenthrin showed significantly $(P<0.01)$ higher levels of GLU, $\mathrm{NH}_{3}$, AST and CK compared to controls.

\subsubsection{Haematological examination after pyrethroid exposure}

Acute exposure of rainbow trout to deltamethrin was associated with significantly higher $(P$ $<0.05$ ) erythrocyte count, haemoglobin content, and haematocrit than in the control group. On the other hand, deltamethrin exposure in common carp led to significantly lower values $(P<0.01)$ of $\mathrm{RBC}, \mathrm{Hb}$ and PCV compared to controls.

Rainbow trout acute exposed to cypermethrin exhibited significantly lower $(P<0.05)$ numbers of developmental forms of myeloid sequence and segmented neutrophilic granulocytes than did untreated fish. Moreover, cypermethrin exposure in common carp resulted in significantly $(P<0.01)$ higher values of $\mathrm{RBC}, \mathrm{MCV}, \mathrm{MCH}$, and lymphocyte count $(P<0.01)$ compared to controls.

Acute exposure of rainbow trout to bifenthrin caused significantly higher $(P<0.01)$ values of $\mathrm{MCV}, \mathrm{MCH}$, and neutrophil granulocyte count compared to controls. In common carp 
bifenthrin was associated only with significantly higher $(P<0.01)$ of monocyte counts compared to control fish.

\subsubsection{Histopathological examination after pyrethroids exposure}

Acute exposure of deltamethrin did not cause histopathological changes in gills, skin, liver, spleen, cranial and caudal kidney of rainbow trout and common carp.

Acute toxicity exposure $(96 \mathrm{~h})$ of cypermethrin caused severe teleagioectasia in the secondary lamellae of gills with the rupture of pillar cells (Fig. 1) and degeneration of hepatocytes, especially in the periportal zones in rainbow tout. Affected hepatocytes showed pycnotic nuclei and many small vacuoles or one large vacuole in the cytoplasm. The shape of vacuoles was typical for fatty degeneration of liver.

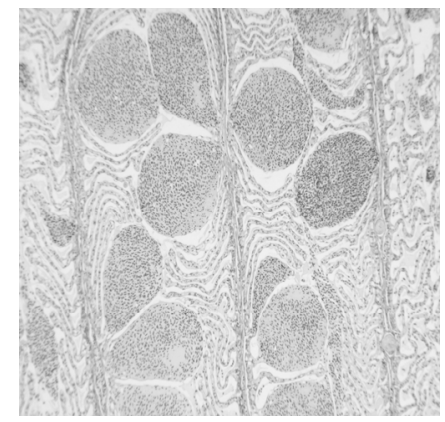

Fig. 1. Gill of rainbow trout with teleangioectasia in the secondary lamellae after acute cypermethrin exposure; H\&E, x100 (from Velisek et al., 2006a).

In carp, acute exposure to cypermethrin resulted in hyperaemia and perivascular lymphocyte infiltration in skin, mild hyperplasia of respiratory epithelium chloride cell activation in the gills (Fig. 2), and vacuolisation of pancreas exocrine cells (Fig. 3).

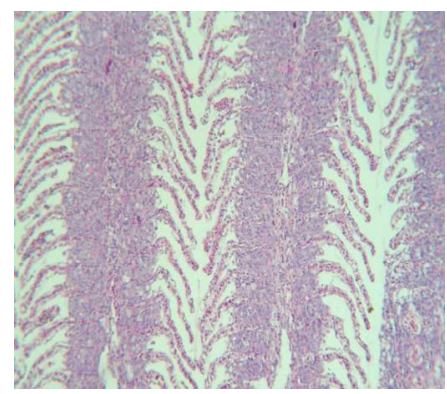

Fig. 2. Mild hyperplasia of respiratory epithelium and activation of chloride cells in carp gills after acute cypermethrin exposure (from Dobsikova et al., 2006).

Acute exposure to bifenthrin in rainbow trout and common carp was associated with degeneration of hepatocytes (Fig. 4), especially in the periportal zones. Affected hepatocytes showed pycnotic nuclei and many small vacuoles or one large vacuole in the cytoplasm. Vacuole shape was typical of fatty degeneration of the liver. Moreover bifenthrin in common carp caused severe teleangioectasia in the secondary lamellae of gills, with the rupture of pillar cells. 


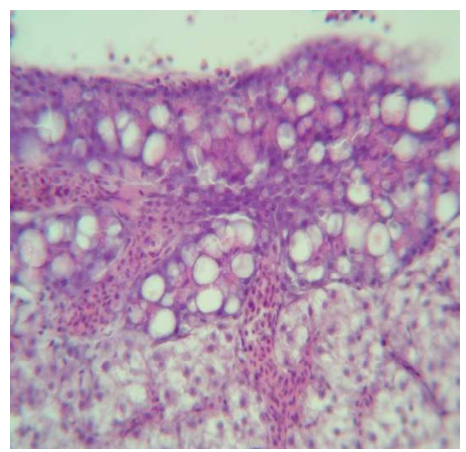

Fig. 3. Vacuoles in pancreatic exocrine carp cells after acute cypermethrin exposure (from Dobsikova et al., 2006).

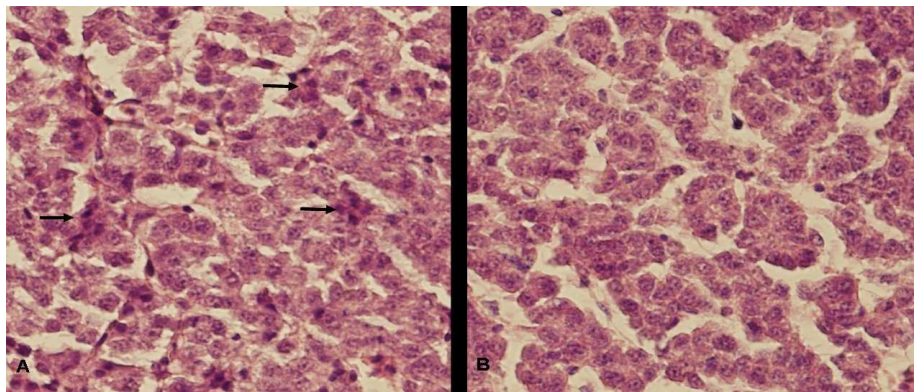

Fig. 4. Liver of rainbow trout after acute exposure to bifenthrin (A) and control (B); H\&E, x100. Note degenerated hepatic cells with pycnotic nuclei (arrows) (from Velisek et al., 2009b).

\subsection{Triazines}

For the long-term test with terbutryn, common carp, $297.38 \pm 55.58 \mathrm{~g}$ mean body weight and $222.3 \pm 18.8 \mathrm{~mm}$ mean total body length, were used. For the long-term test with simazine, common carp, $353.24 \pm 81.67 \mathrm{~g}$ mean body weight and $258.4 \pm 19.6 \mathrm{~mm}$ mean total body length, were used. Common carp were obtained from a commercial hatchery (Vodnany, Czech Republic).

\subsubsection{Fish behaviour after long-term triazine exposure}

During the experiment with terbutryn and simazine both control and exposed common carp showed normal feeding behaviour. There were no signs of respiratory distress such as rapid ventilation, increased rate of gill opercular movements, or floating at the surface of water. There were no mortalities during the experiment.

\subsubsection{Biometric parameters after long-term triazine exposure}

Long-term exposure of terbutryn at concentrations of $0.02 \mu \mathrm{g} / \mathrm{L}, 0.2 \mu \mathrm{g} / \mathrm{L}$, and $2 \mu \mathrm{g} / \mathrm{L}$ had no significant effects on biometric parameters (SL, BW, LW, SW, CF, and HSI) of experimental common carp.

Biometric parameters of common carp exposed to simazine at the recorded environmental concentration of $0.06 \mu \mathrm{g} / \mathrm{L}$ showed no differences from untreated fish. Long-term exposure to 
simazine at concentrations of $2 \mu \mathrm{g} / \mathrm{L}$ and $4 \mu \mathrm{g} / \mathrm{L}$ caused significant increases $(P<0.01)$ in HSI relative to controls. No differences in the remaining parameters $(\mathrm{SL}, \mathrm{BW}, \mathrm{LW}, \mathrm{SW}$, and $\mathrm{CF}$ ) investigated were found among any groups (Kruskal-Wallis test for all comparisons $P>0.05$ ).

\subsubsection{Biochemical results of long-term triazine exposure}

Results of biochemical profiling after terbutryn exposure are given in Table 2. Biochemical profiles of common carp exposed to terbutryn at the recorded environmental concentration of $0.02 \mu \mathrm{g} / \mathrm{L}$ showed no differences from untreated fish. In fish exposed to terbutryn at concentrations of 0.2 and $2 \mu \mathrm{g} / \mathrm{L}$, significant $(P<0.01)$ decreases in the level of CREA and $\mathrm{Mg}$ and a significant $(P<0.01)$ increase in GLU, AST, LDH, and LACT levels in plasma were observed compared with controls. The remaining indices: TP, ALB, GLOB, $\mathrm{NH}_{3}, \mathrm{TAG}, \mathrm{ALT}$, GGT, CK, AMYL, LIPA, ALP, Ca+2, PHOS, VTG, and KT were similar in all groups.

\begin{tabular}{||l|c|c|c|c||}
\hline \hline Fish Group & Control & 1 & 2 & 3 \\
\hline Terbutryn $(\mu \mathrm{g} / \mathrm{L})$ & - & 0.02 & 0.2 & 2 \\
\hline & Mean $\pm \mathrm{SD}$ & Mean $\pm \mathrm{SD}$ & Mean $\pm \mathrm{SD}$ & Mean $\pm \mathrm{SD}$ \\
\hline GLU $(\mathrm{mmol} / \mathrm{L})$ & $4.35 \pm 0.76$ & $4.48 \pm 0.43$ & $9.62 \pm 1.15^{*}$ & $8.54 \pm 1.35^{*}$ \\
\hline AST $(\mu \mathrm{kat} / \mathrm{L})$ & $1.12 \pm 0.26$ & $1.36 \pm 0.19$ & $3.11 \pm 0.25^{*}$ & $3.36 \pm 0.20^{*}$ \\
\hline LDH $(\mu \mathrm{kat} / \mathrm{L})$ & $13.25 \pm 1.28$ & $14.11 \pm 2.35$ & $20.65 \pm 3.62^{*}$ & $21.08 \pm 3.01^{*}$ \\
\hline CREA $(\mathrm{mmol} / \mathrm{L})$ & $50.95 \pm 5.67$ & $48.63 \pm 4.12$ & $30.15 \pm 2.54^{*}$ & $29.78 \pm 3.14^{*}$ \\
\hline LACT $(\mathrm{mmol} / \mathrm{L})$ & $1.28 \pm 0.28$ & $1.02 \pm 0.14$ & $2.63 \pm 0.58^{*}$ & $2.80 \pm 0.36^{*}$ \\
\hline $\mathrm{Mg}(\mathrm{mmol} / \mathrm{L})$ & $1.12 \pm 0.11$ & $1.18 \pm 0.12$ & $0.57 \pm 0.10^{*}$ & $0.48 \pm 0.13^{*}$ \\
\hline
\end{tabular}

Table 2. Derived biochemical parameters in common carp following long-term exposure to terbutryn $(n=16)$ (from Velisek et a., 2011a). *Experimental groups are significantly $(P<$ 0.01) different from the control.

Biochemical profiles after simazine exposure are given in Table 3. Biochemical profiles of common carp exposed to simazine at the recorded environmental concentration of 0.06 $\mu \mathrm{g} / \mathrm{L}$ showed significantly $(P<0.01)$ higher of ALP activity compared to controls.

\begin{tabular}{||l|c|c|c|c||}
\hline Fish Group & Control & 1 & 2 & 3 \\
\hline Simazin $(\mu \mathrm{g} / \mathrm{L})$ & - & 0.06 & 2 & 4 \\
\hline & Mean \pm SD & Mean \pm SD & Mean \pm SD & Mean \pm SD \\
\hline TP $(\mathrm{g} / \mathrm{L})$ & $34.88 \pm 5.58$ & $33.75 \pm 3.63$ & $33.75 \pm 2.44$ & $24.50 \pm 5.36^{*}$ \\
\hline ALB $(\mathrm{g} / \mathrm{L})$ & $5.38 \pm 2.29$ & $4.31 \pm 1.62$ & $5.50 \pm 1.22$ & $1.23 \pm 1.65^{*}$ \\
\hline ALT $(\mu \mathrm{kat} / \mathrm{L})$ & $0.26 \pm 0.08$ & $0.23 \pm 0.09$ & $0.05 \pm 0.02^{*}$ & $0.05 \pm 0.02^{*}$ \\
\hline ALP $(\mu \mathrm{kat} / \mathrm{L})$ & $0.65 \pm 0.04$ & $0.21 \pm 0.09^{* *}$ & $0.23 \pm 0.11^{* *}$ & $0.17 \pm 0.13^{* *}$ \\
\hline
\end{tabular}

Table 3. Derived biochemical parameters in common carp following long-term exposure to simazine $(n=16)$. Experimental groups are significantly ${ }^{* *} P<0.01$ and $* P<0.05$ different from controls (from Velisek et al., 2011b).

Biochemical profiles of carp exposed to simazine at the concentration of $2 \mu \mathrm{g} / \mathrm{L}$ showed significantly higher activity of ALP $(P<0.01)$ and ALT $(P<0.05)$ than controls carp. In carp, simazine at a concentration of $4 \mu \mathrm{g} / \mathrm{L}$ caused a significant increase in TP $(P<0.05)$, ALB $(P<$ $0.05)$, ALP $(P<0.01)$ and ALT activity $(P<0.05)$ compared to controls. 
The remaining indices, GLU, GLOB, $\mathrm{NH}_{3}$, TAG, AST, GGT, LDH, CK, CREA, LACT, AMYL, LIPA, $\mathrm{Ca}^{+2}, \mathrm{Mg}$, PHOS, VTG, and KT were similar in all groups.

\subsubsection{Haematological results of long-term triazine exposure}

Haematological profiles following terbutryn exposure are given in Table 4. Haematological profiles of common carp exposed to terbutryn at the recorded environmental concentration of $0.02 \mu \mathrm{g} / \mathrm{L}$ showed no differences from untreated fish. In fish exposed of terbutryn at concentrations of 0.2 and $2 \mu \mathrm{g} / \mathrm{L}, \mathrm{RBC}$, lymphocyte counts, and mean corpuscular haemoglobin concentrations increased significantly $(P<0.01)$, and Leuko, neutrophil granulocyte bands, and MCV decreased significantly $(P<0.01)$ relative to controls. The values of $\mathrm{Hb}, \mathrm{PCV}$, and $\mathrm{MCH}$ were similar among all groups.

\begin{tabular}{|l|c|c|c|c||}
\hline Fish Group & Control & 1 & 2 & 3 \\
\hline Terbutryn $(\mu \mathrm{g} / \mathrm{L})$ & - & 0.02 & 0.2 & 2 \\
\hline RBC $(\mathrm{T} / \mathrm{L})$ & Mean $\pm \mathrm{SD}$ & Mean $\pm \mathrm{SD}$ & Mean \pm SD & Mean \pm SD \\
\hline $\mathrm{MCV}(\mathrm{fl})$ & $1.36 \pm 0.27$ & $1.25 \pm 0.16$ & $1.89 \pm 0.11^{*}$ & $1.84 \pm 0.10^{*}$ \\
\hline $\mathrm{MCHC}(\mathrm{g} / \mathrm{L})$ & $187.38 \pm 17.67$ & $188.45 \pm 23.84$ & $126.63 \pm 21.70^{*}$ & $132.30 \pm 16.22^{*}$ \\
\hline Leuko $(\mathrm{G} / \mathrm{L})$ & $254.82 \pm 13.24$ & $261.49 \pm 12.30$ & $298.19 \pm 17.83^{*}$ & $294.11 \pm 10.37^{*}$ \\
\hline $\begin{array}{l}\text { Lymphocytes } \\
(\mathrm{G} / \mathrm{L})\end{array}$ & $97.00 \pm 42.16$ & $112.19 \pm 57.88$ & $31.06 \pm 13.43^{*}$ & $28.32 \pm 10.15^{*}$ \\
\hline $\begin{array}{l}\text { Neutrophil } \\
\text { granulocytes bands } \\
(\mathrm{G} / \mathrm{L})\end{array}$ & $86.99 \pm 6.86$ & $104.06 \pm 3.29$ & $12.59 \pm 4.16^{*}$ & $15.86 \pm 3.26^{*}$ \\
\hline
\end{tabular}

Table 4. Derived haematological parameters in common carp following long-term exposure to terbutryn $(n=16)$. *Experimental groups are significantly $(P<0.01)$ different from the control (from Velisek et al., 2011b).

Simazine at concentrations of $0.06 \mu \mathrm{g} / \mathrm{L}, 2 \mu \mathrm{g} / \mathrm{L}$, and $4 \mu \mathrm{g} / \mathrm{L}$ led to significant $(P<0.01)$ decrease in Leuko relative to controls after 90 days exposure. The values for $\mathrm{Hb}, \mathrm{PCV}, \mathrm{MCH}$, $\mathrm{MCV}, \mathrm{MCHC}$, and the Leukogram were similar among all groups.

\subsubsection{Liver biomarkers after long-term triazine exposure}

Long-term exposure to terbutryn at concentrations of $0.02 \mu \mathrm{g} / \mathrm{L}$ (reported environmental concentration in Czech rivers), $0.2 \mu \mathrm{g} / \mathrm{L}, 2 \mu \mathrm{g} / \mathrm{L}$, and simazine at concentrations of 0.06 $\mu \mathrm{g} / \mathrm{L}$ (reported environmental concentration in Czech rivers), $2 \mu \mathrm{g} / \mathrm{L}$, and $4 \mu \mathrm{g} / \mathrm{L}$ had no significant effects on the activity of phase I detoxification enzymes (CYP 450, EROD) and phase II detoxification enzymes (GST, GSH) in liver.

\subsubsection{Histopathology following long-term triazine exposure}

No histopathological anomalies were demonstrated in liver, spleen, or cranial and caudal kidney of carp following long-term exposure to terbutryn at concentrations of $0.02,0.2$, and $2 \mu \mathrm{g} / \mathrm{L}$.

Long-term exposure to simazine at concentrations of $0.06 \mu \mathrm{g} / \mathrm{L}, 2 \mu \mathrm{g} / \mathrm{L}$, and $4 \mu \mathrm{g} / \mathrm{L}$ caused severe hyaline degeneration of the epithelial cells of renal tubules of the caudal kidney (Fig. 5); while, in the control fish, the caudal kidney parenchyma was intact. The altered tubular 
epithelium was atrophic in tubules, with and without casts. Some tubules appear expanded, but, if they did not contain casts, were small with a thickened basement membrane. No histopathological changes were demonstrated in liver, spleen, or cranial kidney following long-term exposure to simazine.

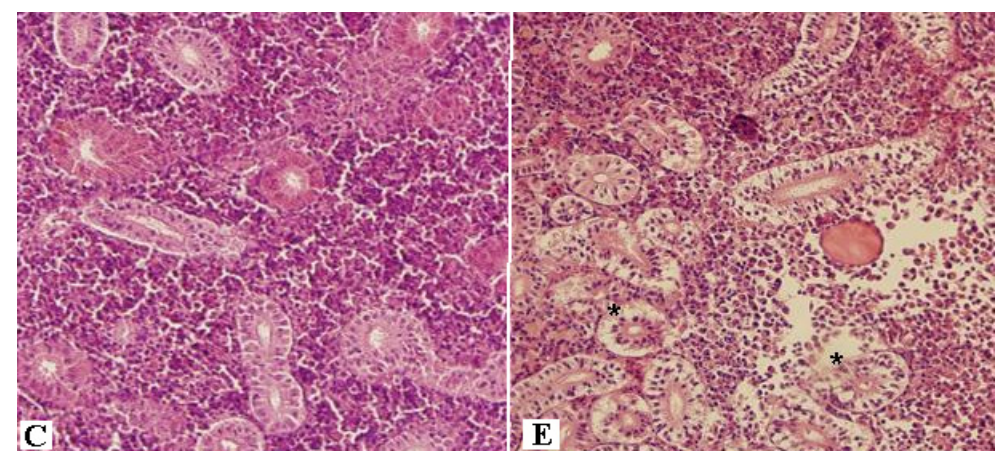

Fig. 5. Caudal kidney of common carp following exposure to simazine in a 90 day trial. $\mathrm{H} \& \mathrm{E}, \mathrm{x} 200 . \mathrm{C}=$ control, $\mathrm{G}=$ group 4 (concentration $4 \mu \mathrm{g} / \mathrm{L}$ of simazine). The asterisks indicate areas of tubule destruction (from Velisek et al., 2011b).

\section{Discussion}

Laboratory studies of physiological responses in fish exposed to pesticides can provide information on, and help to elucidate the mechanisms of, the impact of pesticides on fish. The results reported here provide further data on acute exposure to pyrethroids and chronic exposure to triazine pesticides for consideration in risk assessment.

\subsection{Pyrethroids}

In recent years, awareness of residual pyrethroid pesticides in the aquatic environment is growing as investigations increase and analytical detection techniques improve. Fish exposed to insecticides exhibit a variety of physiological responses, including blood balance disturbances. Laboratory studies of biochemical responses in tissues of fish exposed to insecticides can help to elucidate the mechanism, and provide information on the impact of residual environmental insecticides on fish.

In our study, the 96hLC50 of tested pyrethroid pesticides (deltamethrin, cypermethrin and bifenthrin) was found to be less than $6 \mu \mathrm{g} / \mathrm{L}$. In view of this, deltamethrin, cypermethrin, and bifenthrin were included in the group of substances strongly toxic to fish. Bifenthrin is more toxic at cooler temperatures, and thus more toxic to cold water fish than to warm water species, but the toxicity of pyrethroids is little affected by $\mathrm{pH}$ or water hardness (Mauck et al., 1976). Pyrethroids are more toxic to smaller fish than larger ones (Baser et al., 2003). The values found in the studies were in agreement with data reported by other authors who determined the toxicity of pyrethroid pesticides for various species of fish. Liu et al. (2005) report a 96hLC50 value of $2.08 \mu \mathrm{g} / \mathrm{L}$ and $0.80 \mu \mathrm{g} / \mathrm{L}$ for common carp and tilapia (Tilapia spp.), respectively. Bradbury \& Coats (1989) report mean lethal toxicity of cypermethrin to various fish species in laboratory conditions to be below $10 \mu \mathrm{g} / \mathrm{L}$. Shires (1985) reported the $96 \mathrm{hLC} 50$ value of cypermethrin for rainbow trout to be $2.57 \mu \mathrm{g} / \mathrm{L}$. 
Gangolli (1999) reports the values of 96hLC50 of deltamethrin in common carp and rainbow trout as ranging from 0.0005 to $0.0018 \mathrm{mg} / \mathrm{L}$.

Behaviour observation is considered a promising tool in ecotoxicology, and these studies are becoming prominent in toxicity assessments in many species, including fish. Since behaviour is not a random process, but rather a selective response that is constantly adapting through direct interaction with physical, chemical, social, and physiological aspects of the environment, behavioural endpoints serve as valuable tools to discern and evaluate effects of exposure to environmental stressors, and fish behavioural alterations can provide important indices for ecosystem assessment (Kane et al., 2005). Clinical symptoms (e.g. accelerated respiration, loss of movement and coordination, fish lying at the tank bottom and moving in one spot, subsequent short excitation periods with convulsions and movement in circles) observed during acute exposure of rainbow trout and common carp to pyrethroids (deltamethrin, cypermethrin and bifenthrin) correspond to observations by other authors reporting on the toxicity of pyrethroid pesticides (Dobsikova et al., 2006; Velisek et al., 2006a). Bradbury \& Coats (1989) reported signs of fenvalerate poisoning in fish, that included loss of schooling behaviour, swimming near the water surface, hyperactivity, erratic swimming, seizures, loss of buoyancy, increased cough rate, increased gill mucus secretions, flaring of the gill arches, head shaking, and listlessness before death.

The main acute haematological response of rainbow trout and common carp to the effects of pyrethroid was a significant change in the $\mathrm{RBC}, \mathrm{Hb}, \mathrm{MCV}, \mathrm{MCHC}$, lymphocyte, and segmented neutrophilic granulocyte counts. The reduction in RBC count and PCV value and the higher erythrocyte haemoglobin of fish can be attributed to haemodilution due to damage of organs and changes in the haematological parameters $\mathrm{PCV}, \mathrm{RBC}$, and $\mathrm{Hb}$, which can be interpreted as a compensatory response to increase the $\mathrm{O}_{2}$ carrying capacity of the blood to maintain gas transfer, also indicating a change of the water-blood barrier for gas exchange in gill lamellae. Haematological results indicated decrease in nonspecific immunity. A decrease in $\mathrm{PCV}, \mathrm{Hb}$, Leuko and $\mathrm{RBC}$ has been reported in carp after poisoning with cypermethrin (Dorucu \& Girgin, 2001), and a decrease in total leukocyte count and neutrophil granulocyte count was observed in carp following acute poisoning with permethrin (Sopinska \& Guz, 1998).

The change in blood GLU concentration after pyrethroid exposure demonstrated the response of exposed fish to metabolic stress. Cypermethrin caused an increase in plasma $\mathrm{NH}_{3}$ levels, presumably due to an increase in amino acid catabolism and a failure of ammonia excretion mechanisms. Increased $\mathrm{NH}_{3}$ concentration indicates organism inability to convert the toxic ammonia to less harmful substances. An enhanced energy demand caused by short-term pyrethroid stress stimulates the activity of glutamate dehydrogenase (GDH) which induces glutamate fission into ammonia and a-ketoglutaric acid utilized in the TCA cycle. The enzymes used for the purpose are LDH, CK, and transaminases AST and ALT. A significant increase in the activity of the above mentioned plasma enzymes indicates stress-related tissue impairment. Increased activity of transaminases indicated amplified transamination processes. An increase in transamination occurs with amino acid input into the TCA cycle to cope with the energy crisis during pyrethroid induced stress (Philip et al., 1995). The changes in LDH level indicated metabolic changes, i.e. glycogen catabolism and glucose shift to the formation of lactate in stressed fish, primarily in the muscle tissue. Jee et al. (2005) found an increase in levels of serum glutamic-acid-oxylacetic-acid-transaminase, glutamic-acid-pyruvic-acid-transaminase, GLU, and ALP and a decrease in the concentration of plasma TP, ALB, cholesterol, and lysozyme in Korean rockfish (Sebastes 
schlegeli) exposed to cypermethrin. Balint et al. (1995) observed an increase of GLU in common carp (Cyprinus carpio) after exposure to deltamethrin. Atamanalp et al. (2002) found changes in the concentration of $\mathrm{Ca}^{2+}$ and phosphorus in rainbow trout following cypermethrin exposure.

We observed teleangioectasia of secondary lamellae of the gills and degeneration of hepatocytes in periportal zones in rainbow trout after cypermethrin exposure. Teleangioectasia indicate acute respiratory distress. Sarkar et al. (2005) found significant changes such as hyperplasia, disintegration of hepatic mass, and focal coagulative necrosis in Labeo rohita exposed to cypermethrin. Edwards et al. (1986) reported acute toxicity symptoms of cypermethrin in rainbow trout including gill flailing, hyperactivity, loss of buoyancy, and inability to remain upright. Cengiz (2006) observed histopathological effects of deltamethrin on the gill (desquamation, necrosis, aneurysm in secondary lamellae, lifting of the lamellar epithelium, oedema, epithelial hyperplasia, and fusion of the secondary lamellae) of common carp after acute exposure in concentration of 0.029 and $0.041 \mathrm{mg} / \mathrm{L}$. Acute effects of pyrethroid pesticides in fish include damage of gills and behavioural changes. Because they are highly lipophilic, pyrethroids are likely to be strongly absorbed by the gills, even from water containing low levels of pyrethroids. Degeneration of hepatocytes in periportal zones can imply the influence of toxic compounds in the digestive tract. The biochemical changes in liver profile may also be related to hepatocyte damage. Significant changes such as hyperplasia, disintegration of hepatic mass, and focal coagulative necrosis were found in Labeo rohita exposed to cypermethrin (Jee et al., 2005).

\subsection{Triazines}

In order to make an accurate assessment of the hazards that a contaminant may pose to a natural system, behavioural indices selected for monitoring must reflect the organism's behaviour in the field. Repeated opening and closing of the mouth and opercular movements are obvious indicators of a toxicant's effect in fish. During the laboratory toxicity test, common carp exposed to terbutryn and simazine showed normal feeding habits and exhibited no abnormal behaviour. Velisek et al. (2009b) reported accelerated respiration and loss of movement coordination in rainbow trout and carp following acute poisoning with metribuzin. These characteristics have also been reported in Oreochromis niloticus and Chrysichthyes auratus (Hussein et al., 1996) and in Carassius auratus by Saglio \& Trijasse (1998) following acute poisoning with atrazine. Movement imbalance in freshwater fish (Labeo rohita, Mystus vittatus, and Cirrhinus mrigala) exposed to simazine and cyanazine has been reported by Dad and Tripathi (1980). Oropesa et al. (2009) reported respiratory distress such as rapid ventilation, increased rate of gill cover movements, and floating at the surface of water in common carp after exposure to simazine. Our results differ from these, as, during the assay, both control and exposed carp behaved normally. However, different exposure regimes as well as different fish species were used in our study.

Biometric parameters of common carp exposed to terbutryn or simazine at the recorded environmental concentration had no effects on biometric parameters. Only simazine in concentrations of 2 and $4 \mu \mathrm{g} / \mathrm{L}$ showed increases in HSI relative to controls. Biometric parameters are regarded as general indicators of fish health and the quality of the aquatic environment. The hepatosomatic index is a non-specific biomarker influenced by factors such sex, season, disease, and nutritional level. Dewey (1986) reported reduction in body weight and length and decrease of condition in brook trout (Salvelinus fontinalis) exposed 306 days to atrazine at a concentration of $120 \mu \mathrm{g} / \mathrm{L}$. Davies et al. (1994) observed growth rate reduction in 
the inanga (Galaxias maculatus) following exposure to low concentrations of atrazine. Atrazine, at doses of 100 and $1000 \mu \mathrm{g} / \mathrm{L}$, showed no dose- or time-related effects on gonad growth (GSI) in either males or females over a 21-day study period (Spano et al., 2004).

Biochemical profiles of blood can provide important information about the internal environment of the organism (Masopust, 2000). Biochemical alterations are usually the first detectable and quantifiable responses to environmental change. Chronic exposure to terbutryn at 0.2 and $2 \mu \mathrm{g} / \mathrm{L}$ resulted in a significant increased in plasma GLU concentration, demonstrating the response of exposed fish to metabolic stress. Mekkawy et al. (1996) observed increases in GLU levels in Nile tilapia (Oreochromis niloticus) and catfish (Chrysichtheys auratus) after atrazine exposure at $3 \mathrm{mg} / \mathrm{L}$. Chronic exposure to simazine at $0.06,2$, and $4 \mu \mathrm{g} / \mathrm{L}$ resulted in a significant decrease in plasma ALP activity. The source of ALP includes synthesis in the intestinal epithelium, kidney, and liver and is often increased in response to a biliary obstruction. Velisek et al. (2008) also reported decreased ALP in rainbow trout after acute exposure to metribuzin. Chronic exposure to terbutryn at 0.2 and 2 $\mu \mathrm{g} / \mathrm{L}$ resulted in significant increase in plasma AST and LDH activity. Chronic exposure to simazine at 2 and $4 \mu \mathrm{g} / \mathrm{L}$ resulted in a significant decrease in plasma ALT activity. LDH is the terminal enzyme of anaerobic glycolysis and therefore of crucial importance in muscle physiology, particularly in conditions of chemical stress when high levels of energy may be required for a short period of time (Monteiro et al., 2007). The increase in LDH level indicated metabolic changes, i.e. glycogen catabolism and a glucose shift towards the formation of lactate, primarily in muscle. A significant change in the activity of plasma enzymes LDH and the transaminases ALT and AST indicates stress-based tissue impairment. Change in activity of transaminases indicates amplified transamination processes. An increase in transamination occurs with amino acid input into the TCA cycle to cope with the energy crisis during pesticide stress. It has been suggested that, in general, stress induces elevation of the transamination pathway and is likely to have contributed to toxic effects induced by terbutryn and simazine and the altered transaminase activity observed in the present study. Chronic exposure to simazine at $4 \mu \mathrm{g} / \mathrm{L}$ resulted in significant decrease in plasma TP and ALB concentration. In these circumstances, changes in serum protein concentration might arise from protein leakage from damaged tissue. In the present study, the reduction of plasma protein and albumins with chronic exposure confirms the toxic effects of simazine on the immune system and/or the haemodilution effect, and may account for the pathological effects on caudal kidney. These results agree with Hussein et al. (1996) and Mekkawy et al. (1996) who reported a decrease of TP in atrazine exposed Nile tilapia and catfish. Davies et al. (1994) also observed a decrease in TP in rainbow trout after acute exposure to atrazine at a concentration of $50 \mu \mathrm{g} / \mathrm{L}$. Other authors found changes in biochemical profiles of fish following triazine exposure. Velisek et al. (2009a) found a decrease in the activity of AST and an increase in GLU, $\mathrm{NH}_{3}, \mathrm{LDH}, \mathrm{CK}$, and CREA levels in common carp after subchronic exposure to simazine. The biochemical profiles determined in the present chapter suggest that internal organs and tissue of common carp were slightly altered with exposure to terbutryn and simazine.

The evaluation of haematological characteristics of fish has become an important means of understanding normal and pathological processes and toxicological impacts. Haematological alterations are usually the first detectable and quantifiable responses to environmental change (Wendelaar Bonga, 1997). In our study, simazine was associated with decreased leukocyte count relative to controls. Leukocytes are involved in the regulation of immunological function and a protective response to stress in fish. The reduction in 
leukocyte count occurs through an alteration in lymphopoesis and/or altered release of lymphocytes from lymphoid tissues. The decrease in leukocyte count in the present study indicates the stress condition of the fish subsequent to simazine exposure, which may have produced hypoxia and kidney damage. The response to environmental challenges often leads to leucopenia with lymphopenia and sometimes neutrophilia, which is similar to the classic leukocytic response to stress in mammals (Ainsworth, 1992). In the present study, the decrease in leukocyte count and the lymphopenia in carp exposed to terbutryn indicated a reduction in non-specific immunity. Prolonged stress may have caused disruption of leukopoiesis, resulting in reduction in the total leukocyte count. Exposure to terbutryn was associated with the highest RBC value in fish exposed to the higher concentrations, when stress-induced RBC release from spleen to blood circulation was reported (Tort et al., 2002).. Haematological changes may result from the release of immature erythrocytes from the spleen and could be an immediate response to acute stress mediated by catecholamines. Oropesa et al. (2009) reported no effect on the haematological profiles of common carp exposed to $45 \mu \mathrm{g} / \mathrm{L}$ simazine.

The present experiments attempted to evaluate xenoestrogenic potency of triazine pesticide using vitellogenin and 11-ketotestosterone as a biomarker of exposure to (xeno)oestrogens. The monitoring of VTG and KT are proving to be useful tools for study of the effects of endocrine disrupting chemicals in fish. Synthesis of VTG, a lipophosphoprotein, is induced by oestradiol in the liver of female fish. Its presence in male and juvenile fish indicates contact with xenoestrogenic compounds, since VTG synthesis is oestrogen-dependent. In the presence of substances with oestrogenic effects, synthesis of VTG is carried out in the liver of male fish, which may lead to degenerative alterations of male gonads, reproductive breakdown, and, in extreme cases, sex reversal. Crain et al. (1997) showed that chloro-striazine herbicides have the ability to stimulate production of the enzyme aromatase, which converts androgens to oestrogens, and presumably could interfere with sex differentiation and development. However, terbutryn and simazine did not further influence plasma VTG and KT levels in the exposed fish after 90 days. Moore \& Waring (1998) observed that an atrazine concentration of $3.6 \mu \mathrm{g} / \mathrm{L}$ altered plasma testosterone and, at $6.0 \mu \mathrm{g} / \mathrm{L}$, affected $\mathrm{KT}$ in Atlantic salmon (Salmo salar). Tennant et al. (1994), working with rats, concluded that, while the chloro-s-triazine herbicides atrazine and simazine did not possess any intrinsic oestrogenic activity, these two compounds were capable of weak inhibition of oestrogenstimulated responses in the rat uterus (i.e., effect on progesterone receptor binding and thymidine incorporation into uterine DNA).

Determination of enzymes and cofactors involved in xenobiotic biotransformation is widely practiced for assessment of exposure to pollutants. As compared with phase I systems, the induction responses of phase II enzymes are generally less pronounced. Cytochrome P450, members of a large family of heme proteins, are membrane-bound proteins which are predominantly located in the endoplasmic reticulum of the liver. The CYP450 reactions can be grouped according to the type of substrate and separated into the synthesis and degradation of endogenous substrates and the metabolism of xenobiotic substrates. The presence of the CYP450 1A isoform is expressed as EROD activity. The EROD activity may be indicative of the cytochrome P4501A1 enzyme system function. Induction of EROD is commonly observed in fish and other vertebrates exposed to Ah-receptor agonists (i.e. dioxins, polychlorinated biphenyls, polyaromatic hydrocarbons, pesticides) (reviewed in van der Oost et al., 2003). The liver is probably the most commonly studied organ in preclinical toxicology as a detoxification organ essential for the excretion of toxic substances 
in animals. The major site of cytochrome P450 expression in teleost fish is the liver. Tripeptide glutathione (L-ץ-glutamyl-cysteinyl-glycine; GSH) is a major component of cellular antioxidant defences and a key conjugate of electrophilic intermediates in phase II metabolism. The conjugation reaction is mediated principally via GST. Another function of the GST family is the transport of endogenous hydrophobic compounds, such as steroids, bilirubin, heme, and bile salts, as well as the prevention of lipid peroxidation. It has been reported that terbutryn is able to induce EROD activity in rainbow trout (Tarja et al., 2003). Dong et al. (2009) reported that P450 content in zebrafish (Danio rerio) (both male and female) was induced by atrazine, even at a dose of $0.01 \mathrm{mg} / \mathrm{L}$. Exposure to terbutryn and simazine did not influence CYP concentration or EROD, GST, or GSH activity, suggesting that a role for CYP450 1A in the metabolism of terbutryn and simazine in common carp can be ruled out. In rodents, the dominant phase I metabolic reaction for triazine pesticides is cytochrome P450-mediated N-dealkylation (Hanioka et al., 1999 a,b).

Triazine pesticides have a direct effect on kidney structure and function in freshwater fish (Velisek et al., 2008, 2009b). In our experiment, the caudal kidney of carp with chronic exposure to simazine showed destruction of the tubules, although chronic exposure to terbutryn had no effect on caudal kidney. The kidney is important for the maintenance of a stable internal environment with respect to water and salt, excretion, and, partially, for the metabolism of xenobiotics. In fish, this organ receives the largest proportion of postbranchial blood.

The uptake of triazine via gill seems to be of major significance; therefore renal lesions might be expected to be good indicators of environmental pollution. In addition, this is a target organ of certain toxicants, since it is a major route for the excretion of foreign chemicals. It has been reported that acute and subchronic exposures to triazine result in lesions in kidneys and liver in fish (Velisek et al., 2008, 2009b). Simazine showed no effect on liver of common carp. On the other hand, Velisek et al. (2010) found cell shape changes and lipid inclusions in hepatocytes of common carp with subchronic terbutryn exposure in concentrations of 4, 20, and $40 \mu \mathrm{g} / \mathrm{L}$. Similar alterations in liver were observed by Arufe et al. (2004), who exposed the larvae of gilthead sea bream (Sparus aurata) to terbutryntriasulfuron at a concentration of $2.5 \mathrm{mg} / \mathrm{L}$ for $72 \mathrm{~h}$. Steatosis in liver of grey mullet (Liza ramada) (Biagianti-Risbourg \& Bastide, 1995) has been observed after atrazine exposure and has been proposed as a mechanism of sequestration of the pesticide molecules, protecting fish from toxic effects. Changes in metabolism of hepatic lipids and vacuolar degeneration of hepatocytes have been observed in various fish species exposed to herbicide such as clomazone (Crestani et al., 2007).

\section{Conclusion}

Toxicological and environmental problems resulting from the widespread use of pesticides in agriculture have raised concerns, particularly with respect to the potential toxic effects in humans and animals. The acute exposure of rainbow trout and common carp to the pyrethroids deltamethrin, cypermathrin, and bifenthrin were associated with alterations in haematological and biochemical indices as well as in tissue enzymes, resulting in stress to the organism. These pyrethroids are therefore classified as belonging to substances strongly toxic for fish. Long-term exposure to triazines terbutryn and simazine in environmental concentrations can affect the biochemical, haematological, and biometric profiles of common carp. Some changes were observed only with the higher 
exposures. These results suggest that biometric, blood, liver biomarkers, and histopathological responses could be used as potential biomarkers for monitoring residual pesticides present in aquatic environments and provide useful parameters for evaluating physiological effects in fish, but the application of these findings will need more detailed laboratory study before they can be established as special biomarkers for monitoring the aquatic environment. Other classical morphologic indices (e.g. condition factor and hepatosomatic index) in fish could provide useful information for evaluating environmental stress. It is not clear that whether these pesticide-induced responses in fish were related to the level of stress hormones (especially catecholamines and cortisol), enzymatic kinetics, and molecular mechanisms, which need further investigation. Research should be focused not only on the effects of pesticides alone, but also on interactions of pesticides with other pollutants in environmental concentrations with long-term exposure, since the aquatic environment may be polluted by many substances, the effects of which can be potentiated with concurrent exposures.

\section{Acknowledgment}

This research was supported by the Czech Science Foundation Project No. 525/09/P218, the centre CENAQUA No. CZ.1.05/2.1.00/01.0024, Project No. USB (GAJU) No.047/2010/Z.

\section{References}

Ainsworth, A.J. (1992). Fish granulocytes: morphology, distribution, and function. Annual Review of Fish Diseases, Vol. 2, No. 2, (June 1992), pp. 123-148, ISSN 0959-8030

Arufe, M.I.; Arellano, J.; Moreno, M.J. \& Sarasquetec, C. (2004) Toxicity of a commercial herbicide containing terbutryn and triasulfuron to seabream (Sparus aurata L.) larvae: a comparison with the Microtox test. Ecotoxicology and Environmental Safety, Vol. 59, No. 2, (October 2004), pp. 209-216, ISSN 0147-6513

Atamanalp, M.; Keles, M.S.; Haliloglu, H.I. \& Aras, M.S. (2002):.The effects of cypermethrin (a synthetic pyrethroid) on some biochemical parameters $(\mathrm{Ca}, \mathrm{P}, \mathrm{Na}$ and $\mathrm{TP}$ ) of rainbow trout (Oncorhynchus mykiss). Turkish Journal of Veterinary Animal Sciences, Vol. 26, No. 5, (October 2002), pp. 1157-1160, ISSN 1300-0128

Balint, T.; Szegletes, T.; Szegletes, Z.; Halasy, K. \& Nemcsok, J. (1995). Biochemical and subcellular changes in carp exposed to the organophosphorus methidathion and the pyrethroid deltamethrin. Aquatic Toxicology, Vol.33, No. 3-4, (October 1995) , pp. 279-295, ISSN 0166-445X

Baser, S.; Erkoc, F.; Selvi, M. \& Kocak, O. (2003). Investigation of acute toxicity of permethrin on guppies Poecilia reticulata. Chemosphere, Vol. 51, No. 6, (May 2003), pp. 469-474, ISSN 0045-6535

Belmonte, A.; Garrido, A. \& Martinez, J.L. (2005). Monitoring of pesticides in agricultural water and soil samples from Andalusia by liquid chromatography coupled to mass spectrometry. Analytica Chimica Acta, Vol. 538, No. 1-4, (May 2005), pp. 117-127, ISSN 0003-2670

Biagianti-Risbourg, S. \& Bastide, J. (1995). Hepatic perturbations induced by a herbicide (atrazine) in juvenile grey mullet Liza ramada (Mugilidae, teleostei): an 
ultrastructural study. Aquatic Toxicology, Vol. 31, No. 3, (March 1995), pp. 217-229, ISSN 0166-445X

Bradbury, S.P. \& Coats, J.R. (1989). Toxicokinetics and toxicodynamics of pyrethroid insecticides in fish. Environmental Toxicology and Chemistry, Vol. 8, No. 5, (May 1989), pp. 373-380, ISSN 0730-7268

Cengiz, E.I. (2006). Gill and kidney histopathology in the freshwater fish Cyprinus carpio after acute exposure to deltamethrin. Environmental Toxicology and Pharmacology, Vol. 21, No. 2, (February 2006), pp. 1093-1096, ISSN 1382-6689

Cerejeira, M.J.; Viana, P.; Batista, S.; Pereira, T.; Silva, E.; Valerio, M.J.; Silva, A.; Ferreira, M. \& Silva-Fernandes, A.M. (2003). Pesticides in Portuguese surface and ground waters. Water Research, Vol. 37, No. 5, (March 2003), pp. 1055-1063, ISSN 00431354

Crain, D.A.; Guillette, L.J.; Rooney, A.A. \& Pickford, D.B. (1997). Alterations in steroidogenesis in alligators (Alligator mississippiensis) exposed naturally and experimentally to environmental contaminants. Environmental Health Perspectives, Vol. 105, No.5 , (May 1997), pp. 528-533, ISSN 0091-6765

Cremlyn, R.J. (1990). Agrochemicals; Preparation and mode of action. John Wiley \& Sons Ltd., ISBN 0471929921, West Sussex UK.

Crestani, M.; Menezes, C.; Glusczak, L.; Miron, D.D.; Spanevello, R.; Silveira, A.; Goncalves, F.F.; Zanella, R. \& Loro, V.L. (2007). Effect of clomazone herbicide on biochemical and histological aspects of silver catfish (Rhamdia quelen) and recovery pattern. Chemosphere, Vol. 67, No. 11, (May 2007), pp. 2305-2311, ISSN 0045-6535.

Dad, N.K. \& Tripathi, P.S. (1980). Acute toxicity of herbicides to freshwater fish and midge larvae, Chironomus tentans. Environment International, Vol. 4, No. 5-6, (December 1980), pp. 435-437, ISSN 0160-4120

Das, P.C.; McElroy, W.K. \& Cooper, R.L. (2000). Differential modulation of catecholamines by chlorotriazine herbicides in pheochromocytoma (PC12) cells in vitro. Toxicological Sciences, Vol. 56, No. 2, (August 2000), pp. 324-331, ISSN 1096-6080

Davies, P.E.; Cook, L.S.J. \& Goenarso, D. (1994). Sublethal responses to pesticides of several species of Australian freshwater fish and crustaceans and rainbow trout. Environmental Toxicology and Chemistry, Vol. 13, No. 8, (August 1994), pp. 1341-1354, ISSN 0730-7268

DeLorenzo, M.E.; Scott, G.I. \& Ross, P.E. (2001). Toxicity of pesticides to aquatic microorganisms: A review. Environmental Toxicology and Chemistry, Vol. 20, No. 1, (January 2001), pp. 84-98, ISSN 0730-7268

Dewey, S.L. (1986). Effects of the herbicide atrazine on aquatic insect community structure and emergence. Ecology, Vol. 67, No. 1, (February 1986), pp. 148-162, ISSN 00129658

Dobsikova, R.; Velisek, J.; Wlasow, T.; Gomulka, P.; Svobodova, Z. \& Novotny, L. (2006). Effects of cypermethrin on some haematological, biochemical and histopathological parameters of common carp (Cyprinus carpio L.). Neuroendocrinology Letters, Vol. 27, No. suppl. 2, (December 2006), pp. 101-105, ISSN 0172-780X 
Dong, X.; Zhu, L.; Wang, J.; Wang, J.; Xie, H.; Hou, X. \& Jia, W. (2009). Effects of atrazine on cytochrome P450 enzymes of zebrafish (Danio rerio). Chemosphere, Vol. 77, No. 3, (October 2009), pp. 404-412, ISSN 0045-6535

Dorucu, M. \& Girgin, A. (2001). The effects of cypermethrin on some haematological parameters of Cyprinus carpio. Aquaculture International, Vol. 9, No. 2, (March 2002), pp. 183-187, ISSN 0967-6120

Edwards, R.; Millburn, P. \& Hutson, D.H. (1986). Comparative toxicity of cys-cypermethrin in rainbow trout, frog, mouse and quail. Toxicology and Applied Pharmacology, Vol. 84, No. 3, (December 1986), pp. 512-522, ISSN 0041-008X

Ellman, G.L. (1959). Tissue sulfhydryl groups. Archives of Biochemistry and Biophysics, Vol. 82, No. 1, (May 1959), pp. 70-77, ISSN 0003-9861

Eshleman, A.J. \& Murray, T.F. (1991). Pyrethroid insecticides indirectly inhibit GABAdependent 36Cl-influx in synaptoneurosomes from the trout brain. Neuropharmacology, Vol. 30, No. 12, (December 1991), pp. 1333-1341, ISSN 00283908

European Commission (1999). Study on the prioritisation of substances dangerous to the aquatic environment. Office for Official Publications of the European Communities, Luxembourg 120.

Fan, W.Q.; Yanase, T.; Morinaga, H.; Gondo, S.; Okabe, T.; Nomura, M.; Komatsu, T.; Morohashi, K.I.; Hayes, T.B.; Takayanagi, R. \& Nawata, H. (2007). AtrazineInduced aromatase expression Is SF-1 dependent: implications for endocrine disruption in wildlife and reproductive cancers in humans. Environmental Health Perspectives, Vo. 115, No. 5, (May 2007), pp. 720-727, ISSN 0091-6765

Flammarion, P.; Brion, F.; Babut, M.; Garric, J.; Migeon, B.; Noury, P. \& Thybaud, E. (2000). Induction of fish vitaellogenin and alterations intesticular structure: preliminary results of estrogenic effects in chub (Leuciscus cephalus). Ecotoxicology, Vol. 9, No. 12, (April 2000), pp. 127-135, ISSN 0963-9292

Gangolli, E.D. (1999). The dictionary of substances and their effects. (2nd ed.), Royal of Society of Chemistry, ISBN 0-85404-833-2, Cambridge, UK

Habig, W.H.; Pabst, M.J. \& Jakobi, W.B. (1974). Glutathione-S-transferases. The first enzymatic step in mercapturic acid formation. Journal of Biological and Chemistry, Vol. 249, No. 22, (November 1974), pp. 7130-7139, ISSN 0949-8257

Hashimoto, Y. \& Nishiuchi, Y. (1981). Establishment of bioassay methods for the evaluation of acute toxicity of pesticides to aquatic organisms. Journal of Pesticide Science, Vol. 6, No. 2, (May 1981), pp. 257-264, ISSN 0385-1559

Haya, K. (1989). Toxicity of pyrethroid insecticides to fish. Environmental Toxicology and Chemistry, Vol. 8, No. 5, (May 1989), pp. 381-391, ISSN 0730-7268

Hayes, A.W. (1994). Principles and methods of toxicology. Raven Press, ISBN 0-7817-0131-7, New York, NY.

Hanioka, N.; Jinno, H.; Tanaka-Kagawa, T.; Nishimura, T. \& Ando, M. (1999a). In vitro metabolism of chlorotiazines: characterization of simazine, atrazine, and propazine metabolism using liver microsomes from rats with various cytochrome P450 inducers. Toxicology and Applied Pharmacology, Vol. 156, No. 3, (May 1999), pp. 195205, ISSN 0041-008X 
Hanioka, N.; Jinno, H.; Tanaka-Kagawa, T.; Nishimura, T. \& Ando, M. (1999b). In vitro metabolism of simazine, atrazine, and propazine by hepatic cytochrome P450 enzymes of rat, mouse and guinea pig and oestrogenic activity of chlorotriazines and their main metabolites. Xenobiotica, Vol. 29, No. 12, (December 1999), pp. 12131226, ISSN 0049-8254

Hussein, S.Y.; El-Nasser, M.A. \& Ahmed, S.M. (1996). Comparative studies on the effects of herbicide atrazine on fresh water fish Oreochromis niloticus and Chrysichthyes auratus at Assiut, Egypt. Bulletin of Environmental Contamination and Toxicology, Vol. 57, No. 3, (September 1996), pp. 503-510, ISSN 0007-4861

Inoue, M.H.; Oliveira, R.S.; Regitano, J.B.; Tormena, C.A.; Constantin, J. \& Tornisielo, V.L. (2006). Sorption-desorption of atrazine and diuron in soils from southern Brazil. Journal of Environmental Science and Health Part B, Vol. 41, No. 5, (June 2006), pp. 605-621, ISSN 0360-1234

Jee, L.H.; Masroor, F. \& Kang, J.C. (2005). Responses of cypermethrin-induced stress in haematological parameters of Korean rockfish, Sebastes schlegeli (Hilgendorf). Aquaculture Research, Vol. 36, No. 9, (June 2005), pp. 898-905, ISSN 1365-2109

Katsumata, H.; Fujii, A.; Kaneco, S.; Suzuki, T. \& Ohta, K. (2005). Determination of simazine in water samples by HPLC after preconcentration with diatomaceous earth. Talanta, Vol. 65, No. 1, (January 2005), pp. 129-134, ISSN 0039-9140

Kane, A.S.; Salierno, J.D. \& Brewer, S.K. (2005). Fish models in behavioral toxicology: Automated techniques, updates and perspectives. In: Methods in Aquatic Toxicology, Ostrander, GK, pp. 559-590, Lewis Publishers, ISBN 978-1-56670-664-3, Boca Raton, FL

Kidd, H. \& James, D.R. (1991). The Agrochemicals Handbook. (3rd ed.), Royal Society of Chemistry Information Services, ISBN 085186416 3, Cambridge, UK.

Konstantinou, I.K.; Hela, D.G. \& Albanis, T.A. (2006). The status of pesticide pollution in surface waters (rivers and lakes) of Greece. Part I. Review on occurrence and levels. Environmental Pollution, Vol. 141, No. 3, (June 2006), pp. 555-570, ISSN 0269-7491

Larsen, L.; Sorensen, S.R. \& Aamand, J. (2000). Mecroprop, isoproturon, and atrazine in and above a sandy aquifer: vertical distribution of mineralization potential. Environmental Science and Technology, Vol. 34, No. 12, (May 2000), pp. 2426-2430, ISSN 0013-936X

Liu, T.L.; Wang, Y.S. \& Yen, J.H. (2005). Separation of bifenthrin enantiomers by chiral HPLC and determination of their toxicity to aquatic organism. Journal of Food and Drug Analysis, Vol. 12, No. 3, (September 2005), pp. 357-360, ISSN 1021-9498

Lowry, O.H.; Rosebrough, N.J.; Farr, A.L. \& Randall, R.J. (1951). Protein measurement with the Folin phenol reagent. Journal of Biological and Chemistry, Vol. 193, No. 1, (November 1951), pp. 265-275, ISSN 0949-8257

Mauck, W.L.; Olson, L.E., \& Marking, L.L. (1976). Toxicity of natural pyrethrins and five pyrethroids to fish. Archives of Environmental Contamination and Toxicology, Vol. 4, No. 1, (February 1976), pp. 18-29, ISSN 0090-4341

Masopust, J. (2000). Clinical biochemistry. Karolinum, ISBN 8071846493, Praha, (In Czech). Meister, R.T. (1992). Farm Chemicals Handbook. Meister Publishing Company, Willoughby 
Mekebri, A.; Crane, D.B.; Blondina, G.J.; Oros, D.R. \& Rocca, J.L. (2008). Extraction and analysis methods for the determination of pyrethroid insecticides in surface water, sediments and biological tissues at environmentally relevant concentrations. Bulletin of Environmental Contamination and Toxicology, Vol. 80, No. 5, (May 2008), pp. 455-460, ISSN 0007-4861

Mekkawy, A.A.; Hussain, S.Y. \& Ahmed, S.M. (1996). Comparative studies on the effects of herbicide atrazine on some blood constituents and protein electrophoretic patterns of Oreochromis niloticus and Chrysichthyes auratus at Assiut, Egypt. Journal of the Egyptian German Society of Zoology, Vol. 19, No. 4, (January 1996), pp. 283-319, ISSN 1110-5321

Monteiro, M.; Quintaneiro, C.; Noqueira, A.J.A.; Morgado, F.; Soares, A.M.V.M. \& Guilhermino, L. (2007). Impact of chemical exposure on the fish Pomatoschistus microps Krøyer (1838) in estuaries of the Portuguese Northwest coast. Chemosphere, Vol. 66, No. 3, (January 2007), pp. 514-522, ISSN 0045-6535

Moore, A. \& Waring, C.P. (1998). Mechanistic effects of a triazine pesticide on reproductive endocrine function in mature male Atlantic salmon (Salmo salar L.) parr. Pesticide Biochemistry and Physiology, Vol. 62, No. 1, (October 1998), pp. 4150, ISSN 0048-3575

Muir, D.C. (1980). Determination of terbutryn and its degradation products in water sediments, aquatic plants, and fish. Journal of Agricultural Food Chemistry, Vol. 28, No. 4, (July 1980), pp. 714-719, ISSN 0021-8561

Niimi, A.J. (1987). Biological half-lives of chemicals in fishes. Reviews Environmental Contamination and Toxicology, Vol. 99, No. 1, (January 1987), pp. 1-46, ISSN 01795953

Ormad, M.P.; Miguel, N.; Claver, A.; Matesanz, J.M. \& Ovelleiro, J.L. (2008). Pesticides removal in the process of drinking water production. Chemosphere, Vol. 71, No. 1, (March 2008), pp. 97-106, ISSN 0045-6535

Oropesa, A.L.; Garcia-Cambero, J.P.; Gomez, L.; Roncero, V. \& Soler, F. (2009). Effect of long-term exposure to simazine on histopathology, hematological, and biochemical parameters in Cyprinus carpio. Environmental Toxicology, Vol. 24, No. 2, (April 2009), pp. 187-99, ISSN 1522-7278

Philip, G.H.; Reddy, P.M. \& Sridevi, G. (1995). Cypermethrin-induced in vivo alterations in the carbohydrate metabolism of freshwater fish, Labeo rohita. Ecotoxicology and Environmental Safety, Vol. 31, No. 2, (July 1995), pp. 173-178, ISSN 0147-651

Rioboo, C.; Prado, R.; Herrero, C. \& Cid, A. (2007). Population growth study of the rotifer Brachionus sp. Fed with triazine-exposed microalgae. Aquatic Toxicology, Vol. 83, No. 4, (August 2007), pp. 247-253, ISSN 0166-445X

Richter, S. \& Nagel, R. (2007). Bioconcentration, biomagnification and metabolism of 14Cterbutryn and 14C-benzo[a]pyrene in Gammarus fossarum and Asellus aquaticus. Chemosphere, Vol. 66, No. 4, (June 2007), pp. 603-610, ISSN 0045-6535

Roberts, T. \& Hudson, D. (1999). Metabolic pathway of agrochemicals. Part 2: insecticides and fungicides (1st ed.), The Royal Society of Chemistry, ISBN 085404499X, Cambridge 
Roberts, T.R.; Hutson, D.H.; Lee, P.W.; Nicholls, P.H. \& Plimmer, J.R. (1998). Metabolic Pathways of Agrochemicals. Part 1: Herbicides and Plant growth regulators. (1st ed.) The Royal Society of Chemistry, ISBN 0854044949, Cambridge, UK

Sarkar, B.; Chatterjee, A.; Adhikari, S. \& Ayyappan, S. (2005). Carbofuran- and cypermethrin-induced histopathological alterations in the liver of Labeo rohita (Hamilton) and its recovery. Journal of Applied Ichthyology, Vol. 21, No. 2, (April 2005), pp. 131-135, ISSN 1439-0426

Shan, G.; Hammer, R.P. \& Ottea, J.A. (1997). Biological activity of pyrethroid analogs in pyrethroid-susceptible and -resistant tobacco budworms, Heliothis virescens (F.). Journal of Agricultural Food and Chemistry, Vol. 45, No. 11, (November 1997), pp. 4466-4473, ISSN 0021-8561

Shires S.W. (1985): Toxicity of a new pyrethroid insecticide, WL 85871, to rainbow trout. Bulletin of Environmental Contamination and Toxicology, Vol. 34, No. 2, (February 1985), pp. 134-137, ISSN 0007-4861

Siroka, Z.; Krijt, J.; Randak, T.; Svobodova, Z.; Peskova, G.; Fuksa, J.; Hajslova, J.; Jarkovsky, J. \& Janska, M. (2005). Organic pollutant contamination of the River Elbe as assessed by biochemical markers. Acta Veterinaria Brno, Vo. 74, No. 2, (June 2005), pp. 293-303, ISSN 0001-7213

Solomon, K.R.; Baker, D.B.; Richards, R.P.; Dixon, K.R.; Klaine; S.J.; Point, T.W.; Kendall, J.; Weisskopf, C.P.; Giddings, J.M.; Giesy, J.P.; Hall, L.W. \& Williams, W.M. (1996). Ecological risk assesment of atrazine in North American surface waters. Environmental Toxicology and Chemistry, Vol. 15, No. 1, (January 1996), pp. 31-76, ISSN 0730-7268

Solomon, K.R.; Giddings, J.M. \& Maund, S.J. (2001). Probabilistic risk assessment of cotton pyrethroids: I. Distributional analysis of laboratory aquatic toxicity data. Environmental Toxicology and Chemistry, Vol. 20, No. 3, (March 2001), pp. 652-659, ISSN 0730-7268

Sopinska, A. \& Guz, L. (1998). Influence of permethrin on phagocytic activity of carp. Medycyna Weterynaryjna, Vol. 54, No. 2, (February 1998), pp. 126-128, ISSN 00258628

Spalding, R.F.; Exner, M.E.; Snow, D.D.; Cassada, D.A.; Burbach, M.E. \& Monson, S.J. (2003). Herbicides in ground water beneath Nebraska's management systems evaluation area, Journal of Environmental Quality, Vol. 32, No. 1, (January 2003), pp. 92-98, ISSN 0047-2452

Spano, L.; Tyler, C.R.; van Aerle, R.; Devos, P.; Mandiki, S.N.M.; Silvestre, F.; Thomec, J.P. \& Kestemont, P. (2004). Effects of atrazine on sex steroid dynamics, plasma vitellogenin concentration and gonad development in adult goldfish (Carassius auratus). Aquatic Toxicology, Vol. 66, No. 4, (March 2004), pp. 369-379, ISSN 0166$445 X$

Svobodova, Z.; Pravda, D. \& Palackova, J. (1991). Unified methods of haematological examination of fish. Research Institute of Fish Culture and Hydrobiology, Vodnany, Methods No. 20, pp. 31

Takashima, F. \& Hibiya, T. (1995). An atlas of fish histology: Normal and pathological features, (2nd ed.), Kodansha Ltd., ISBN 987-3437307829, Tokyo 
Tarja, N.; Kirsti, E.; Marja, L. \& Kari, E. (2003). Thermal and metabolic factors affecting bioaccumulation of triazine herbicides by rainbow trout (Oncorhynchus mykiss). Environmental Toxicology, Vol. 18, No. 4, (July 2003), pp. 219-226, ISSN 1522-7278

Tennant, M.K.; Hill, D.S.; Eldridge, J.C.; Wetze, L.T.; Breckenridge, C.B. \& Stevens, J.T. (1994). Possible antiestrogenic properties of chloro-s-trianzines in rat uterus. Journal of Toxicology and Environmetal Health, Vol. 43, No.2 , (October 1994), pp. 183-196, ISSN 1528-7394

Tomlin, C. (2003). The Pesticide Manual: A World Compendium. (13th ed.), British Crop Protection Council, ISBN 0901436445, Hampshire, UK

Tort, L.; Puigcerver, M.; Crespo, S. \& Padros, F. (2002). Cortisol and haematological response in sea bream and trout subjected to the anesthetics clove oil and 2phenoxyethanol. Aquaculture Research, Vol. 33, No. 11, (September 2002), pp. 907910, ISSN 1365-2109

Treasurer, J.W. \& Wadsworth, S.L. (2004). Interspecific comparison of experimental and natural routes of Lepeophtheirus salmonis and Caligus elongatus challenge and consequences for distribution of chalimus on salmonids and therapeutant screening. Aquaculture Research, Vol. 35, No. 8, (July 2004), pp. 773-83, ISSN 13652109

U.S. EPA - Environmental protection agency (1994). Atrazine, simazine and cyanazine: notice of initiation of special review. Federal register 59 FR60412, Vol. 59, No. 225, 30000-60.

van der Oost, R.; Beyer, J. \& Vermeulen, N.P.E. (2003). Fish bioaccumulation and biomarkers in environmental risk assessment: a review. Environmental Toxicology and Pharmacology, Vol. 13, No. 2, (February 2003), pp. 57-149, ISSN 1382-6689

Velisek, J., Sudova, E., Zlabek, V., Kolarova, J., Svobodova, Z. (2011a). Effects of chronic exposure to terbutryn in common carp (Cyprinus carpio L.). Veterinarni Medicina, in press, ISSN 0375-8427

Velisek, J., Stara, A., Machova, J., Svobodova, Z. (2011b). Effects of long-term exposure to simazine in real concetration on common carp (Cyprinus carpio L.). Ecotoxicology and Environmental Safety, in press, ISSN 0147-6513

Velisek, J.; Sudova, E.; Machova, J. \& Svobodova, Z. (2010). Effects of sub-chronic exposure to terbutryn in common carp (Cyprinus carpio L.). Ecotoxicology and Environmental Safety, Vol. 73, No. 3, (March 2010), pp. 384-390, ISSN 0147-6513

Velisek, J.; Stastna, K.; Sudova, E.; Turek, J. \& Svobodova, Z. (2009a). Effects of subchronic simazine exposure on some biometric, biochemical, hematological and histopatological parameters of the common carp (Cyprinus carpio L.). Neuroendocrinology Letters, Vol. 30, No. Suppl. 1, (December 2009), pp. 236-241, ISSN 0172-780X

Velisek, J.; Svobodova, Z. \& Piackova, V. (2009b). Effects of acute exposure to bifenthrin on some haematological, biochemical and histopathological parameters of rainbow trout (Oncorhynchus mykiss). Veterinarni Medicina, Vol. 54, No. 3, (March 2009), pp. 131-137, ISSN 0375-8427

Velisek, J., Svobodova, Z., Machova, J., (2009c). Effects of bifenthrinu on some haematological, biochemical and histopathological parameters of common carp 
(Cyprinus carpio L.). Fish Physiology and Biochemistry, Vol. 35, No. 4, (November 2009), pp. 583-590, ISSN 09201742

Velisek, J.; Svobodova, Z.; Piackova, V.; Novotny, L.; Blahova, J.; Sudova, E. \& Maly, V. (2008). Effects of metribuzin on rainbow trout (Oncorhynchus mykiss). Veterinarni Medicina, Vol. 53, No. 6, (July 2008), pp. 324-332, ISSN 0375-8427

Velisek, J., Jurcikova J., Dobsikova, R., Svobodova, Z., Piackova, V., Machova, J., Novotny, L. (2007). Effects of deltamethrin on rainbow trout (Oncorhynchus mykiss). Environmental Toxicology and Pharmacology, Vol. 23, No. 3, (May 2007), pp. 297-301, ISSN 1382-6689

Velisek, J.; Wlasow, T.; Gomulka, P.; Svobodova, Z.; Dobsikova, R.; Novotny, L. \& Dudzik, M. (2006a). Effects of cypermethrin on rainbow trout (Oncorhynchus mykiss). Veterinarni Medicina, Vol. 51, No. 10, (October 2006), pp. 469-476, ISSN 0375-8427

Velisek, J., Dobsikova, R., Svobodova, Z., Modra, H., Luskova, V. (2006b). Effect of deltamethrin on the biochemical profile of common carp (Cyprinus carpio L.). Bulletin of Environmental Contamination and Toxicology, Vol. 76, No. 6, (June 2006), pp. 992-998, ISSN 0007-4861

Wackett, L.P.; Sadowsky, M.J.; Martinez, B. \& Shapir, N. (2002). Biodegradation of atrazine and related s-triazine compounds: from enzymes to field studies. Applied Microbiology and Biotechnology, Vol. 58, No. 1, (January 2002), pp. 39-45, ISSN 01757598

Wendelaar Bonga, S.E. (1997). The stress response in fish. Physiology Reviews, Vol. 77, No. 3, (July 1997), pp. 591-625, ISSN 0031-9333

Yadav, R.S.; Srivastava, H.C.; Adak, T.; Nanda, N.; Thapar, B.R.; Pant, C.S.; Zaim, M. \& Subbarao, S.K. (2003). House-scale evaluation of bifenthrin indoor residual spraying for malaria vector control in India. Journal of Medical Entomology, Vol. 40, No. 1, (January 2003), pp. 58-63, ISSN 0022-2585 


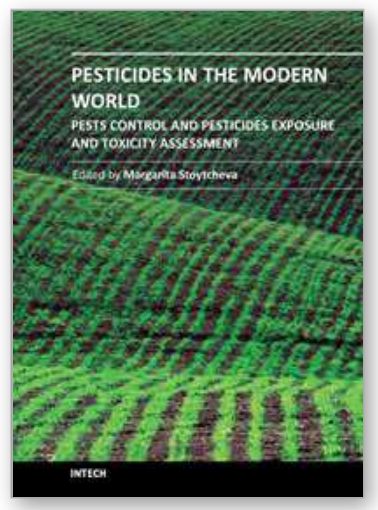

\section{Pesticides in the Modern World - Pests Control and Pesticides Exposure and Toxicity Assessment}

Edited by Dr. Margarita Stoytcheva

ISBN 978-953-307-457-3

Hard cover, 614 pages

Publisher InTech

Published online 30, September, 2011

Published in print edition September, 2011

The present book is a collection of selected original research articles and reviews providing adequate and upto-date information related to pesticides control, assessment, and toxicity. The first section covers a large spectrum of issues associated with the ecological, molecular, and biotechnological approaches to the understanding of the biological control, the mechanism of the biocontrol agents action, and the related effects. Second section provides recent information on biomarkers currently used to evaluate pesticide exposure, effects, and genetic susceptibility of a number of organisms. Some antioxidant enzymes and vitamins as biochemical markers for pesticide toxicity are examined. The inhibition of the cholinesterases as a specific biomarker for organophosphate and carbamate pesticides is commented, too. The third book section addresses to a variety of pesticides toxic effects and related issues including: the molecular mechanisms involved in pesticides-induced toxicity, fish histopathological, physiological, and DNA changes provoked by pesticides exposure, anticoagulant rodenticides mode of action, the potential of the cholinesterase inhibiting organophosphorus and carbamate pesticides, the effects of pesticides on bumblebee, spiders and scorpions, the metabolic fate of the pesticide-derived aromatic amines, etc.

\section{How to reference}

In order to correctly reference this scholarly work, feel free to copy and paste the following:

Josef Velisek, Alzbeta Stara and Zdenka Svobodova (2011). The Effects of Pyrethroid and Triazine Pesticides on Fish Physiology, Pesticides in the Modern World - Pests Control and Pesticides Exposure and Toxicity Assessment, Dr. Margarita Stoytcheva (Ed.), ISBN: 978-953-307-457-3, InTech, Available from: http://www.intechopen.com/books/pesticides-in-the-modern-world-pests-control-and-pesticides-exposure-andtoxicity-assessment/the-effects-of-pyrethroid-and-triazine-pesticides-on-fish-physiology

\section{INTECH}

open science | open minds

\author{
InTech Europe \\ University Campus STeP Ri \\ Slavka Krautzeka 83/A \\ 51000 Rijeka, Croatia \\ Phone: +385 (51) 770447 \\ Fax: +385 (51) 686166 \\ www.intechopen.com
}

\author{
InTech China \\ Unit 405, Office Block, Hotel Equatorial Shanghai \\ No.65, Yan An Road (West), Shanghai, 200040, China \\ 中国上海市延安西路65号上海国际贵都大饭店办公楼 405 单元 \\ Phone: +86-21-62489820 \\ Fax: +86-21-62489821
}


(C) 2011 The Author(s). Licensee IntechOpen. This chapter is distributed under the terms of the Creative Commons Attribution-NonCommercialShareAlike-3.0 License, which permits use, distribution and reproduction for non-commercial purposes, provided the original is properly cited and derivative works building on this content are distributed under the same license. 